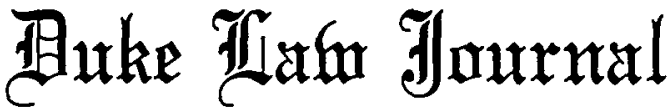

\begin{tabular}{lll}
\hline VOLUME 1978 & OCTOBER & NUMBer 4 \\
\hline
\end{tabular}

\section{THE ROLE OF COUNSEL IN THE SUPPRESSION OF TRUTH}

\author{
A. KenNeth PyE*
}

\section{INTRODUCTION}

The subject of this Article is the role of defense counsel in the suppression of truth in criminal cases. To understand this role, it is necessary to explore briefly the nature of the legal profession.

The special privileges associated with membership in a learned profession, such as the law, are not conferred by society primarily to benefit the members of that profession or their clients. Special status is conferred because of the belief that the society as a whole will benefit from the existence of a specialized group which by education and experience is able to perform functions that a progressive society needs. ${ }^{1}$ Society has conferred upon members of the legal profession a monopoly over the rendition of legal services. The people have also chosen, thus far, to abstain from all but the most general regulation of the profession, delegating to it the power of self-regulation and providing it with public authority to support its efforts. Inherent in such a decision is the assumption that the profession, having been accorded the privileges of monopoly and of self-regulation, will engage in self-regulation

* Chancellor and Professor of Law, Duke University. B.A. 1951, University of Buffalo; J.D. 1953, LL.M. 1955, LL.D. 1978, Georgetown University. The author's views on the subject were presented in a speech given in 1976 at Mercer University and in 1977 at The Judge Advocate General's School.

THE FOLLOWING CITATIONS WILL BE USED IN THIS ARTICLE:

ABA CODE OF Professional Responsibility (1969) [hereinafter cited as CPR];

aba Project on Standards for Criminal Justice: Standards Relating to the DeFENSE FUNCTION (Approved Draft 1971) [hereinafter cited as ABA STANDARDS].

1. MacIver, The Social Significance of Professional Ethics, 297 AnNaLs 118 (1955); Wade, Public Responsibilities of the Learned Professions, 21 LA. L. Rev. 130, 131-36 (1960). 
designed to ensure that these services will be rendered in a manner that will best serve the public interest.

Thus far, that assumption has not proven entirely accurate. The failure of the legal profession adequately to meet this public expectation does not, of course, suggest that the legal profession is in jeopardy of extinction in our lawyer-dominated society. It does suggest that the public may decide to abandon its traditional attitude of abstention and greatly intensify public regulation of the profession.

Few within the profession question the wisdom of effective selfregulation. The real issue is the kind of self-regulation that will best serve the public interest. The American Bar Association in its Code of Professional Responsibility (CPR) attempts to divide the process of self-regulation into two quite different general tasks-what Raymond Marks and Darlene Cathcart have described as the task of monitoring ethical conduct and the task of maintaining quality of performance. ${ }^{2}$ The principal standard for monitoring performance is Disciplinary Rule 6-101, which forbids a lawyer from handling alone a legal matter that he knows, or should know, he is incompetent to handle, prohibits the handling of a legal matter without preparation adequate under the circumstances and forbids neglect of a legal matter entrusted to him. ${ }^{3}$

The following discussion is confined to the other area of self-regulation, the ethical standards of the profession, which deal directly with the problem of what conduct should be prohibited and what should be permitted. The specific focus will be. on permissible conduct by defense counsel in a criminal trial, although many of the observations that follow will be applicable to other kinds of representation and to other processes.

The proper balance between zealous representation and the obligation of the lawyer to the court and to the public is not a new problem. It festers in the background, erupting periodically as during the debates surrounding Charles Phillips' defense of Courvoisier a century ago, ${ }^{4}$ the discussion concerning the views of Mr. Curtis a generation $\mathbf{a g o}^{5}$ and the celebrated lecture and article by Dean Freedman a decade ago. ${ }^{6}$

2. Marks \& Cathcart, Discipline Within the Legal Profession: Is It Self-Regulation?, 1974 ILL. L.F. 193, reprinted in RESEARCH CONTRIBUTIONS OF THE AMERICAN BAR Foundation No. 5 (1974).

3. CPR D.R. 6-101.

4. See D. Mellinkoff, The Conscience of a Lawyer (1973).

5. See C. CURTIS, IT'S YOUR LAW (1954).

6. Freedman, Professional Responsibility of the Criminal Defense Lawyer: The Three Hardest Questions, 64 MICH. L. Rev. 1469 (1966). The questions faced by Dean Freedman were:

(1) Is it proper to cross-examine for the purpose of discrediting the reliability or credibility of an adverse witness whom you know to be telling the truth?

(2) Is it proper to put a witness on the stand when you know he will commit perjury? 
Normally, little happens in the aftermath of such debates. Thus, shortly after the discussion inspired by Dean Freedman's article, the $\mathrm{CPR}$, while concentrating upon the litigator and virtually ignoring the office lawyer, nevertheless managed to deal only obliquely with most of the basic issues that counsel regularly face in criminal litigation. ${ }^{7}$ Uncharacteristically, however, the American Bar Association Standards Relating to the Defense Function, ${ }^{8}$ approved in 1971, did meet many of the issues directly and, motivated in part by strong feelings on the part of the Chief Justice, ${ }^{9}$ specifically rejected Dean Freedman's proposed solutions to what he has called the Three Hardest Questions. ${ }^{10}$ Unlike the CPR, the Standards, which were approved by the Council of the Section on Criminal Justice and the House of Delegates, thus far lack the binding effect of law, but it would be naive to believe that the view of the organized bar will be ignored by disciplinary authorities called upon to interpret the more general language of the Code. ${ }^{11}$ Further consideration is now being given to amending the Code to conform its mandates to the more specific language of the Standards. ${ }^{12}$

The 1971 Standards did not end the debate. In 1974 Judge Marvin E. Frankel, in his Cardozo lecture, The Search for Truth: An

(3) Is it proper to give your client legal advice when you have reason to believe that the knowledge you give him will tempt him to commit perjury?

Id. 1469.

The first question is answered affirmatively. An attorney, according to Dean Freedman, is obligated to cross-examine such truthful witnesses because to do otherwise would "inevitably" impair the confidential attorney-client relationship. Id. 1475. The confidentiality of the attorney-client relationship, the likelihood that the perjured testimony would appear anyway even if the attorney withdrew, the difficulties faced by attorneys representing indigent clients in attempting to withdraw, the inappropriateness of shifting the ethical problem to the judge through a motion to withdraw if the intended perjury comes to light only at trial (but see text accompanying note 95 infra for a contrary view) and the damage done to the client by failing to argue zealously the client's version of the facts, see note 100 infra and accompanying text, all lead Dean Freedman to the conclusion that it is proper to put the perjurious witness on the stand. Freedman, supra, at 1476-78. The third question is also answered affirmatively, since "to decide otherwise would not only penalize the less well-educated defendant, but would also prejudice the client because of his initial truthfulness in telling his story in confidence to the attorney." Id. 1481-82.

7. For instance, CPR D.R. 7-106(C) sets forth seven disciplinary rules for trial conduct.

8. ABA STANDARDS.

9. See Burger, Standards of Conduct for Prosecution and Defense Personnel: A Judge's Viewpoint, 5 AM. CRIM. L. REv. 11 (1966).

10. See note 6 supra.

11. See United States v. DeCoster, 487 F.2d 1197 (D.C. Cir. 1973), discussing the effectiveness of counsel. "Counsel should be guided by the American Bar Association Standards for the Defense Function. They represent the legal profession's own articulation of guidelines for the defense of criminal cases." Id. at 1203.

12. Review of the Code is being conducted by the ABA Special Committee on Evaluation of Professional Standards with Dean L. Ray Patterson of Emory University School of Law serving as Reporter. 
Umpireal View, ${ }^{13}$ echoed Judge Walter V. Schaefer's earlier question ${ }^{14}$ as to whether the present adversary system is serving the public interest in the ascertainment of truth..$^{15}$ As a tentative remedy for his concerns, Judge Frankel recommended some fundamental changes in the manner in which counsel should function. ${ }^{16}$ Shortly thereafter, Dean Freedman published his book modifying and expanding upon his thesis of a decade ago and engaging in a running rebuttal of the ABA Standards, particularly the views of the Chief Justice. ${ }^{17}$

The purpose of the following discussion is to explore the problem again, but from a somewhat different perspective. The beginning point is concern with the difficulties inherent in determining the obligation of counsel to his client and society. The Article rejects the notion that the obligation to client justifies counsel in serving as a "mouthpiece" in the sense of permitting counsel to behave as a client might wish to behave himself if he possessed the requisite talent. It also rejects the notion that it is the role of counsel to assist in every way in the ascertainment of all the facts relevant to a determination of guilt or innocence and, if guilt is found, to the imposition of an appropriate sanction. Rather, the Article argues that the appropriate balance is best determined by examining the purposes of the criminal process and the degree to which

13. Frankel, The Search for Truth: An Umpireal View, 123 U. PA. L. REv. 1031 (1975). See also Freedman, Judge Frankel's Search for Truth, 123 U. PA. L. REv. 1060 (1975); Uviller, The Advocate, The Truth, and Judicial Hackles: A Reaction to Judge Frankel's Idea, 123 U. PA. L. REv. 1067 (1975).

14. W. Schaefer, The Suspect and Society: Criminal Procedure and Converging Constitutional Doctrines (1967).

15. Frankel, supra note 13, at 1032.

16. These changes included requiring an attorney (unless prevented from doing so by a privilege reasonably believed to apply) to report to the court and opposing counsel the existence of relevant evidence when the attorney does not intend to introduce it, to prevent the making of untrue statements and the omission of material facts by the attorney's client or witness, and to question witnesses with the purpose of developing the whole truth. Id. 1057-58.

17. See M. Freedman, LAwYers' Ethics in AN ADVERSARY SySTEM (1975).

See also the differing views of Peter Schuck and Alvin B. Rubin in Can It be Ethical to Lef Your Client Lie on the Stand?, 6 JuRIs Doctor, Feb. 1976, at 49. Other contributions to the debate are Babcock, Problems in Professional Responsibility, 55 NeB. L. Rev. 42 (1975); Callan \& David, Professional Responsibility and the Duty of Confidentiality: Disclosure of Client Misconduct in an Adversary System, 29 RuTGers L. REv. 332 (1976); Glazer, What Are Limits of Lawyer's Professional Conduct in Defending a Client?, 50 FLA. B.J. 332 (1976); Polster, The Dilemma of the Perjurious Defendant: Resolution Not Avoidance, 28 CASE W. RES. L. Rev. 3 (1977); Redlich, Lawyers, the Temple and the Market Place, 30 Bus. LAw. S-65 (1975); Reichstein, The Criminal Law Practitioner's Dilemma: What Should the Lawyer Do When His Client Intends to Testify Falsely?, 61 J. CRIM. L. CRIMINology \& Police ScI. 1 (1970); Rubin, A Causerie on Lawyers' Ethics in Negotiation, 35 LA. L. REv. 577 (1975); Sevilla, Between Scyllo and Charybdis: The Ethical Perils of the Criminal Defense Lawyer, 2 NAT'L J. CRIM. DEF. 237 (1976); Shaffer, Christian Theories of Professional Responsibility, 48 S. CAL. L. Rev. 721 (1975); Wolfram, Client Perjury, 50 S. Cal. L. Rev. 809 (1977); Essay, Three Discussions of Legal Ethics, 126 U. PA. L. REv. 452, 458 (1977); Rotunda, Book Review, 89 HaRv. L. Rev. 622 (1976). 
different defense tactics contribute to or impede the achievement of those purposes.

The Article advances the view that such an evaluation will lead most dispassionate observers to the conclusion that the scales are at present tilted too much in favor of conduct likely to preclude the jury's ascertainment of the relevant facts. It proposes that the most appropriate way of dealing with the problem is primarily through re-examination and alteration of evidentiary and procedural law, not through ethical proscriptions that would preclude counsel from asserting rights that are available to his client under law. In some instances, changes or clarifications are needed in the CPR; in others, the reasons for permitting certain conduct should be articulated in a manner calculated to convince the public.

\section{Truth as a Value in a Criminal Trial}

Our criminal process has undergone radical change in the last century. In the middle of the nineteenth century relevant evidence of guilt was admissible without regard to the manner in which it was obtained, ${ }^{18}$ the accused was not permitted to testify in his own defense ${ }^{19}$ and most defendants were unrepresented. ${ }^{20}$ Defendants charged with serious crimes are now almost invariably represented; they may testify; and relevant evidence is sometimes suppressed if obtained unlawfully.

The process has changed substantially, and the ethics of advocacy can be properly understood only in the context of the procedure that now exists. Although few would like to return to the nineteenth century model, many are concerned about the twentieth century process as it has developed in recent years. Changes in criminal procedure during the last two decades and many current ideas about legal ethics combine to raise serious questions whether the role of defense counsel as we now understand it really is in the public interest, and whether the public will or should remain quiescent if the legal profession accepts such a conception of the role of counsel as a model for professional deportment, at least in the absence of a more persuasive rationale than has been thus far presented. There can be little doubt that any defense counsel would at times be remiss in his duties under existing law if he

18. But see Weeks v. United States, 232 U.S. 383 (1914) (enunciation of the federal exclusionary rule). See also Mapp v. Ohio, 367 U.S. 643 (1961) (application of the exclusionary rule to the states).

19. 2 J. Wigmore, ON EVIDENCE $\$ \S 575,579$ (3d ed. 1940).

20. Indeed, at earlier common law, although the defendant had "the right to the advice and assistance of counsel, he could not be represented by counsel at his trial." W. CLARK, HANDBOoK of Criminal Procedure § 157, at 506 n.30 (2d ed. 1918). 
did not take action that would make the disclosure of the truth less likely in a particular case. It is less clear what criteria should be utilized in determining when such conduct is preferred and when it is not.

Judge Frankel makes a strong case for his conclusion that truth is ranked "too low among the values that institutions of justice are meant to serve."21 Efforts aimed at the ascertainment of truth must be central to the role of counsel in any system for the resolution of disputes. ${ }^{22}$ Conduct that is intended to, or is likely to, result in the suppression of truth, or which is designed to mislead a court or jury or to facilitate a falsehood, should be presumptively improper. Such conduct, if justifiable at all, may be defended in terms of the degree to which it furthers some other valid objective of the system. Other objectives of the system must themselves be re-examined if in concert they preclude the ascertainment of truth.

The propriety of courtroom conduct does not depend upon its importance to counsel in justifying a fee, its value to a client in obtaining an acquittal or its symbolic value to a movement or cause. Unlike the ascertainment of truth, these cannot be said to be fundamental values of the institutions of justice. Nor may a lawyer's conduct be justified solely by the (partially inaccurate) observation of Justice Frankfurter that "ours is the accusatorial as opposed to the inquisitorial system,"23 and that the adversary system will be weakened unless counsel is permitted to undertake whatever action will improve the chance of his client to prevail in the case.

A trial is not an athletic contest in which each side should have an equal chance to win. A defendant should win only when he is innocent or when the state cannot prove his guilt beyond a reasonable doubt by competent evidence according to law. A defendant whose guilt can be proved by competent evidence has no inherent right to an acquittal. He may be acquitted because the prosecution errs, or for some other reason not related to his guilt, but not because of any sense of entitlement.

In most cases the resources available to a defendant are much less than those available to the state, and in some cases they may border on the inadequate. The rules of procedure at a criminal trial reflect an

21. Frankel, supra note 13, at 1032. But cf. G. HaZARD, Ethics in the Practice of Law 128-29 (1978) ("The real value of the adversary system . . . may not be its contribution to truth but its contribution to the ideal of individual autonomy," $i d .129$ ).

22. "The basic purpose of a trial is the determination of truth . . ." Tehan v. United States ex rel. Shott, 382 U.S. 406, 416 (1966).

23. Watts v. Indiana, 338 U.S. 49,54 (1949). Certainly, the decision to arrest, the decision to charge and the proceedings before a grand jury more closely resemble components of an "inquisitorial system." 
allocation of power between the individual and the state. But a criminal trial is not a process designed to reallocate power. Some believe that a conviction is so pointless, so calculated to do nothing but harm to the convicted man and so little good for anyone else, that the most socially conscious and ethical lawyer can wholeheartedly feel it is his duty to secure an acquittal in any permissible way. ${ }^{24}$ Such lawyers need to be reminded that members of the bar are not Platonic Guardians. In a democracy, the people determine what conduct merits the imposition of criminal sanctions and the nature of those sanctions. So far they have not delegated the power to determine such issues to individual lawyers.

A half century ago Judge Learned Hand commented that American criminal prodecure "has been always haunted by the ghost of the innocent man convicted." 25 This is still true today and, on the whole, is probably fortunate. It should not obscure the fact that anyone with experience in the criminal courts knows that many, if not most, defendants brought to felony trial are guilty. ${ }^{26}$ Only a small percentage of people who commit serious crimes are caught, and a high percentage of those who are arrested either plead guilty to lesser charges or are beneficiaries of a decision by the prosecutor not to charge them with a felony. Others are released at preliminary hearings or by grand juries. Still others plead guilty in exchange for favorable sentences. Those who remain in the dock at the beginning of a felony trial are the final product of an administrative screening system ${ }^{27}$ which, with all its

24. See Griffiths, Ideology in Criminal Procedure or a Third "Model" of the Criminal Process, 79 Y ALE L.J. 359 (1970).

25. United States y. Garsson, 291 F. 646, 649 (S.D.N.Y. 1923).

26. See C. AlLEN, Legal Duties 255 (1931), quoted in A. Goldstein \& L. ORLAND, CrimINAL Procedure 4 (1974). "The magnanimous disposition of our law towards the accused is the more striking because it is perfectly well known to every intelligent person that the vast majority of accused persons are guilty of the crimes with which they are charged." Id. Indeed, the operation of a responsible police force and the effective screening of cases by prosecutors, preliminary magistrates and grand juries should avoid the specter of any substantial number of innocent persons suffering the trauma of a felony trial. This in no way suggests that any particular accused should not be entitled to a presumption of innocence.

The fallacy that indictment means guilt is not reduced by the fact that the police are honest and competent and that the probabilities are therefore great that the accused committed the crimes charged against them. . . But the overriding considerations are that reliance is on rational procedure to determine guilt or innocence, and that, whatever police competence and the statistics suggest, we cannot form any intelligent judgment on this basis with reference to any particular case.

Hall, Objectives of Federal Criminal Procedural Revision, 51 YALE L.J. 723, 729 (1942), quoted in A. Goldstein \& L. ORLAND, supra, at 7.

27. For a graphic representation of the relative volume of cases at various stages throughout the criminal justice system, see PRESidenT's COMMISSION ON LAW ENFORCEMENT AND ADMINIStration of Justice, The Challenge of Crime in a Free Society 8-9 (1967), reprinted in H. VetTer \& C. Simonsen, Criminal. Justice in America 6-7 (1976). 
vices, assures us that the innocent defendant is a rarity, the exceptions noted by Professor Borchard ${ }^{28}$ and the Franks ${ }^{29}$ notwithstanding.

Given the probability that the defendant is guilty, the defense counsel, unlike the television lawyer, cannot expect that a prosecution witness will confess on cross-examination or that a diligent investigation will reveal the true culprit. Indeed, he will often admit to himself that his client will win only if counsel is successful in preventing the truth from being disclosed. A hypothetical case may illustrate these concerns better than rhetoric.

\section{ARMEd RobBery IN FARMVILLE}

On October 15, 1977, two men robbed a small branch bank in Farmville, State of Justice. Farmville, with a population of 4,000, is the largest town in Kenan County, a rural area of 400 square miles in the eastern part of the state.

On October 17, 1977, one of the six deputy sheriffs of Kenan County received an anonymous telephone call informing him that the proceeds of the robbery could be found in back of a refrigerator in a mobile home located in a trailer park in the suburbs of Farmville. The deputy did not know the identity of the caller and had no clues to the identity of the robber. He proceeded to the trailer park, located the mobile home, knocked and, when he received no answer, entered. A sack with the name of the bank stenciled on it, and containing the money taken from the bank minus about $\$ 300$ was found in the place described by the anonymous informant. The deputy ascertained the identity of the occupant of the mobile home from the manager of the trailer park. The mobile home was staked out, but no one attempted to enter it. The occupant, John Smith, whose lease on the mobile home had two weeks to run, was arrested several days later in another city. He was wearing a new two-hundred-dollar suit when arrested.

Smith was brought to the sheriff's office in Kenan County. He was informed that the robbery proceeds had been found in the mobile home he had been leasing. He was also informed that he could remain silent and that anything he said could be used against him. He was not informed of his right to counsel. No force, threats or promises were used. Smith admitted that the mobile home was leased to him and that he owned a car similar to that used in the robbery. He stated that he had left Farmville before the robbery and had never intended to return.

28. See E. Borchard, Convicting the InNocent: ERrors of Criminal Justice (1932).

29. See J. Frank \& B. Frank, Not Guilty (1957). 
The next morning Smith was brought before a district judge who informed him of his right to remain silent, his right to counsel, his right to bail and his right to a probable cause hearing. Smith said he would retain counsel. He was unable to post bond. The case was continued for seven days for a probable cause hearing.

Four days later, the district attorney obtained an indictment from a grand jury. Under the law of the state, the indictment mooted the scheduled probable cause hearing. The next day the deputy sheriff, without notifying the district attorney, conducted a lineup at which one witness, a Ms. Young, identified Smith as the driver of the getaway car. She could not state whether he had ever been in the bank. The lineup was conducted fairly, except that Smith was not represented by counsel.

At his arraignment, Smith informed the court he could not afford a lawyer. The court entered a plea of not guilty and appointed Tim Jones to represent him. Jones talked to the district attorney and then went to the jail to interview Smith. He introduced himself and told Smith that before asking him what happened he would first tell him something about the law relating to his case. He then explained to Smith that if he and someone else had agreed to rob the bank he would be technically guilty if he were the driver of the getaway car, although he had never entered the bank. On the other hand, he would be innocent if he had simply agreed to drive a friend to the bank, had no knowledge of the friend's intention to rob it and had driven him away without knowing the bank had been robbed. In addition, he certainly would not be guilty if he were not involved at all. Unfortunately, the state had two witnesses who would testify that he was in the car. Jones went on to tell Smith that if he admitted that he was involved in the bank robbery, Jones would continue to represent him but that he was doubtful whether he could call Smith as a witness in the case, and that if he did not call Smith to the stand, the jury would probably find him guilty.

Smith thought for a few moments and announced that he was the driver of the car but was not involved in the robbery. His friend, Tom Edwards, had asked him to take him to the bank. He knew nothing about the sack behind the refrigerator and did not know where Edwards might be at the present time. He had told the police he was not in Farmville because he was afraid the sheriff would "pin the crime on him" if he admitted he was at the bank. Subsequently, Jones' investigation revealed two witnesses who had been with Smith in Farmville on the day of the robbery. 
The deputy sheriff learned the identity of his informant before trial. The informant had previously provided reliable information to a number of law enforcement agents in the state but was unknown to the deputy, who only recently had joined the office. The informant had not identified himself because he had assumed that the deputy knew him.

Jones promptly filed a motion to suppress the sack of money, the admission of the defendant and the eyewitness testimony of Ms. Young. At the hearing on the motion, it became clear that the court was prepared to hold that a warrantless search of a dwelling based on an anonymous tip by an informant not then known to be reliable was unlawful and that evidence obtained as a result of such a search should be admissible on the grounds of abandonment since the defendant had left the mobile home with no intent to return. Jones argued that Smith still had a right of occupancy by virtue of the lease and, consequently, had not abandoned the mobile home or its contents. In support of the motion, Smith testified that he was an occupant of the mobile home and that he had left Farmville on the day after the robbery but had intended to return before the lease expired. The judge stated that he did not believe that the defendant had intended to return, but that he was still troubled over the issue whether the abandonment doctrine should apply when the defendant's lease had not expired. He clearly indicated that he would like to sustain the search but felt that he could not do so in the absence of authority.

There is no case in point in the State of Justice, but a recent case in point had been decided by the supreme court of a neighboring state, answering the exact issue in favor of the state. Jones knew of the case, but both the district attorney and the judge were unaware of it. Indeed, there is no set of the foreign state reports within fifty miles of Farmville. Jones did not inform the court of the case. The court suppressed the sack and its contents. Smith's admissions were also suppressed under Miranda $v$. Arizona. ${ }^{30}$ The court deferred decision on the admissibility of Ms. Young's testimony until trial.

Prior to trial, Jones contacted some psychology students at a local university. Impressed by the use of psychological profiles at the Joan Little trial, ${ }^{31}$ they and their professor agreed to develop and administer a questionnaire designed to develop a profile of jurors that could be computer-programmed to indicate which personality types would be most likely to vote for acquittal and which would be most likely to vote

30. 384 U.S. 436 (1966).

31. See McConahay, Mullin \& Frederick, The Uses of Social Science in Trials with Political and Racial Overtones: The Trial of Joan Little, 41 LAW \& CoNTEMP. Pros. 205 (1977). 
for conviction. Armed with this study, Jones conducted the voir dire examination and exercised his challenges with the object of choosing only those persons who were likely to acquit if the evidence developed as he planned.

The district attorney called Ms. Young as his first witness. Ms. Young testified out of the presence of the jury that she could not honestly say that her ability to identify the defendant as the driver of the getaway car was unaffected by her identification at the lineup. On objection by Jones, the court excluded her testimony.

The district attorney then called Mr. Roberts, an elderly janitor. $\mathrm{He}$ testified that he had been walking on the street near the bank and had seen a person-whom he identified from a picture as being Edwards-run from the bank carrying a sack and jump into a car driven by the defendant.

Utilizing the discovery procedure available under state law, Jones had learned that fifteen years earlier Roberts had been convicted of the offense of indecent liberties with a child. Jones had also learned that Roberts had undertaken psychiatric treatment following his conviction, married, moved to Farmville and lived a blameless life for over a decade. He was a janitor in a private school for girls, which would probably fire him if his conviction were revealed. The psychological profile suggested that revelation of the prior conviction would have great impact upon several of the jurors. Under state law, the conviction was admissible evidence relating to the credibility of the witness despite the passage of time. Jones had also learned that Roberts usually wore glasses, but on the morning in question was not wearing them. Jones impeached Roberts by interrogating him concerning the prior conviction. He then interrogated him about the absence of his glasses, making it appear doubtful that he could have seen the events he described on direct examination.

The prosecution rested, and the defendant's motion for a directed verdict was denied on the ground that the jury could convict if it believed Roberts. The trial was recessed for the evening. Jones met with Smith to discuss his testimony. The defendant suggested that it might be better if he testified that he was not in Farmville on the day of the robbery in view of the facts that his admissions, the sack and its contents, and Ms. Young's testimony had not been admitted and that Mr. Roberts' testimony had been generally discredited. Jones conceded that such testimony might be more helpful because it would be consistent with his pre-trial statement and thus might provide a basis for blocking the district attorney from admitting the pre-trial statement under the guise of impeachment. But Jones reminded Smith that two 
people had seen him in Farmville on the day of the robbery and admonished him to tell the truth. Smith asked if the district attorney knew about the two witnesses, and Jones answered in the negative. Smith laughed and said, "You can depend on me."

The next morning Jones called Smith to the stand and, after some preliminary questions, asked him whether he was in the car at the bank on the day of the robbery. Smith answered in the negative, adding that he had left town previously to seek employment in another county, never intending to return. Jones asked several other general questions, approached the bench, and requested that the jury be excused. The judge granted the request. Jones then moved to withdraw, indicating that his motion was based on ethical considerations that he was not at liberty to disclose. The court denied the motion with the statement, "Do the best you can. This trial has already taken two days and if I appoint another lawyer, he will be faced with the same problem."

The jury returned and Jones continued his examination, eliciting from Smith testimony that he was in no way involved in the robbery, did not know Edwards, was employed in another county when arrested, and had used his first pay check and some savings to buy the clothes he was wearing at the time of his arrest.

On cross-examination, the district attorney attempted to admit Smith's pre-trial statement to the deputy sheriff. When Jones objected, the court ruled that its tenor was consistent with Smith's testimony on direct examination and was thus inadmissible.

At this point the district attorney requested a recess for three days on the grounds that Edwards had just been apprehended in another state. The court granted the recess. Edwards was brought back to Farmville and was charged with robbery but was released on bond. He retained counsel and entered into an agreement with the district attorney to plead guilty and to testify against Smith in exchange for the promise that the district attorney would recommend a sentence not to exceed five years.

When Jones learned that Edwards had made the deal, he talked again with Smith. Smith responded to the news by informing Jones that he was in fact a partner in the robbery and that Edwards might testify to that effect. Smith then asked whether the district attorney knew of the other evidence. Jones expressed surprise. The defendant then informed Jones that a Mr. Anders knew about the robbery but would not come forward voluntarily because "I have told him what my friends would do to him." In addition, Smith revealed for the first time that the gun used in the robbery was hidden over a false ceiling in the mobile home. 
Utilizing discovery, Jones learned of the arrangements for leniency in exchange for testimony between the district attorney and Edwards and of Edwards' record of two prior felony convictions. Over the objection of Jones, Edwards testified that Smith was his confederate. Jones impeached Edwards' testimony by cross-examining him concerning his prior convictions and his deal with the district attorney.

The district attorney offered as evidence Smith's earlier testimony in support of his motion to suppress the bank sack and money that he had left after the robbery with the intention to return. Jones objected on the ground that a statement by a defendant in support of a motion to suppress is inadmissible to prove guilt under the doctrine of Simmons v. United States. ${ }^{32}$ The court sustained the objection. The district attorney then urged that the earlier testimony should be admitted to impeach Smith's credibility. Jones' objection on the grounds that no proper foundation had been laid on cross-examination was also sustained.

In closing argument, Jones argued that the janitor and Edwards should be disbelieved and that Smith should be believed.

You may reach your own verdict.

\section{The INTERRELATIONSHIP OF ETHICS AND EVIDENCE}

At every stage of the proceeding, defense counsel was totally dedicated to preventing disclosure of the truth. Through the use of the law and his talents, assisted by something less than brilliance on the part of the prosecutor and, arguably, rulings by the trial court, he was extremely successful. It is, of course, difficult to conceive of all of these ethical questions arising in a single case. The point is that most of them arise frequently. The purpose of the hypothetical example is to suggest the degree to which professional ethics and procedural law are intertwined.

Many of what appear at first blush to be ethical questions actually are questions about the wisdom of our rules of evidence and procedure. ${ }^{33}$ Many of the ethical issues are raised only when the problem is put in terms of whether the defense counsel should use an existing procedure or rule of evidence to advance the cause of his client. If we do

32. 390 U.S. 377, 394 (1968). But cf. United States v. Kahan, 415 U.S. 239 (1974) (protection against self-incrimination through use of pretrial statements at trial does not extend to false statements of indigency that are knowingly made).

33. So long as the advocate in the American system is supposed to be at once a champion in forensic roughhouse and a guardian of the temple of justice, he can fulfill his responsibilities only if he combines extraordinary technical skill with an unusually disciplined sense of probity. That seems to be asking too much of any profession.

G. HAZARD, supra note 21 , at 135 . 
not approve of what Jones is doing, the better course of action in several instances may be to change the rule of procedure rather than to conclude that counsel should not utilize a rule favorable to his client, even if the invocation of the rule tends to suppress the truth or mislead the jury.

Presumably, all would agree that there are no ethical problems involved in Jones' agreement to represent Smith. Although he may well have believed when he entered the case that Smith was guilty, guilty people are clearly entitled to a lawyer, and Jones was acting in the finest tradition of the profession in accepting the court appointment to represent a client who could not afford counsel. ${ }^{34}$ It does not necessarily follow, however, that his belief in his client's guilt-or, indeed, his later knowledge of his client's guilt-should have no impact upon the manner in which he should behave in his representation. As to some tactics, such as suppression of evidence obtained in violation of the Constitution, counsel's knowledge or belief that his client is guilty may be irrelevant. Other aspects of his behavior, such as suggesting to his client advantageous versions of possible facts before soliciting his testimony, continuing to examine his client on the stand when he knew he was lying, and urging the jury to disbelieve witnesses he knew to be truthful and to believe his client, whom he knew to be lying, raise issues far more controversial.

\section{A. Principles for Assessment of Courtroom Conduct.}

The propriety of such tactics should be determined first by ascertaining the purposes of a criminal trial and then by determining the responsibilities entrusted to defense counsel in achieving those objectives. The traditional objectives of our system for the adjudication of criminal cases have been, first, the ascertainment of the truth of charges against the defendant and of his defense to the charges; second, the determination of an appropriate sanction if a defendant is found guilty; and, third, the assurance that the fact-finding and dispositional processes are performed in accordance with law, that is, that the law and facts are fairly applied. ${ }^{35}$ An integral part of the fact-finding process is the responsibility of the state to prove its case beyond a reasonable doubt. Our society recognizes that these objectives may not always

34. CPR E.C. 2-25, E.C. 2-29.

35. Some would concede an additional "nonrational" function, i.e., to provide a forum that serves as a "vicarious avenue of emotional release" and that reflects the "conflict between conscious and animal desire," Hall, supra note 26, at 734; to provide a place to vindicate the public's "sense of justice," $i d$; or to serve other "complex psychological functions," Goldstein, The Siate and the Accused: Balance of Advantage in Criminal Procedure, 69 YALE L.J. 1149, 1150 (1960). 
be achieved and expects that courts may arrive at "wise and informed" decision more often than at the "truth," but still strives for the ascertainment of truth by means that are both fair and effective. More recently, we have added a fourth objective: that of deterring law enforcement agents from violating legal statutes, rules and the Constitution. Under certain circumstances, this objective is met by suppressing some of the evidence obtained as a result of their misconduct. ${ }^{36}$ The accomplishment of these objectives has been facilitated by first permitting, and then mandating, counsel for a defendant in the absence of waiver. ${ }^{37}$

The term "adversary system" is the generic description of the procedures and practices by which society has entrusted to counsel principal responsibility for the investigation and presentation of evidence under evidentiary rules designed in general to ensure a high degree to reliability. ${ }^{38}$ Society has placed responsibility upon counsel rather than choosing another alternative, such as entrusting the evidence gathering and presentation process to court officials. This system has been called the "only effective means for combatting this natural human tendency to judge too swiftly in terms of the familiar that which is not yet fully known." 39 Thoughtful people have disagreed about the objectives of the adversary system-for example, whether it is a substitute for out-of-court brawls, ${ }^{40}$ or, in the words of Macaulay, whether the fairest decision will emerge "when two men argue, as unfairly as possible, on opposite sides,"

36. See Mapp v. Ohio, 367 U.S. 643 (1961).

37. See Argersinger v. Hamlin, 407 U.S. 25 (1972); Gideon v. Wainwright, 372 U.S. 335 (1963).

38. See Professional Responsibility: Report of the Joint Conference, 44 A.B.A.J. 1159 (1958).

The distinguished philosopher, Martin Golding, has attempted to categorize the justifications for the adversary system most frequently asserted. See Golding, On the Adversary System and Justice, in Philosophical Law 98 (R. Bronaugh ed. 1978). Golding proposes three theories of justification: (1) the truth finding theory, ie., "an adversarial trial promotes decisions that are well grounded on both the law and the facts because each side will, with partisan zeal, bring to the court's attention all the material favorable to that side, and, therefore, no relevant consideration will escape notice," id. 106; (2) the satisfaction theory, i.e., that the system is justified by the "psychological satisfaction that it gives to the parties in the case, in particular, "the sense of having had a day in court," id. 112; and (3) the protection theory, i.e., that "irrespective of whether a trial aims at truth discovery or something else, justice requires that the parties be given a fair trial of their cause" and that a "fair" trial is either necessarily an adversarial trial or that, at least, "the rights of litigants . . . are best protected under . . . a system in which each side is represented by a partisan advocate," id. 116.

39. Professional Responsibility: Report of the Joint Conference, supra note 38, at 1160.

40. See J. Frank, Courts on Trial: Myth and Reality in AMERICAN Justice 80 (1949).

41. Id. 
for the satisfaction of the parties. ${ }^{42}$ Presumably, most would recognize that the adversary system is not an end in itself; it is a means to certain ends-the objectives of our system for disputes resolution. The decision to permit counsel greater or lesser freedom in taking action on behalf of a client should be judged primarily in terms of its impact upon the objectives of the adversary system, not in terms of its impact on the system itself. ${ }^{43}$

It must be recognized that all institutions and processes tend to develop a dynamic of their own over the passage of time, and the adversary system is no exception. In the lifetime of some of us, the presumption of innocence has developed from a shorthand expression signifying that guilt in a criminal trial must be proved beyond a reasonable doubt to an independent value enshrined in our legal system. ${ }^{44}$ Thus, we talk of an accused being presumed innocent after a magistrate has found probable cause justifying his arrest, after a judge has found probable cause following a contested hearing to hold him for a grand jury and after a grand jury has found probable cause justifying an indictment. ${ }^{45}$ Likewise, the standard of guilt beyond a reasonable doubt has been elevated from a highly desirable standard of proof in criminal cases to a matter of due process of law in juvenile hearings. ${ }^{46}$ And so it is with the adversary system. Over the passage of time the need to encourage each counsel to fulfill his responsibilities has produced rules

42. C. Curtis, supra note 5, at 3. See also Curtis, The Ethics of Advocacy, 4 STAN. L. REv. 3 (1951).

43. Several of the theses underlying the adversary system have been studied recently. See Thibaut, Walker \& Lind, Adversary Presentation and Bias in Legal Decisionmaking, 86 HARV. L. REv. 386 (1972). These studies have been incorporated into J. THIBAuT \& L. WALKER, Procedural Justice: A Psychological Analysis (1975). See also Lind, Thibaut \& Walker, Discovery and Presentation of Evidence in Adversary and Nonadversary Proceedings, 71 Mich. L. REv. 1129 (1973).

44. Compare Taylor v. Kentucky, 98 S. Ct. 1930 (1978), Mullaney v. Wilbur, 421 U.S. 684 (1975) and Coffin v. United States, 156 U.S. 432 (1895) with C. MCCoRMICK, EvIDENCE 647-49 (1954):

As applied to the accused, any assumption, or "presumption" of innocence, in the popular sense of an inference based on probability, is absurd. . . . The assumption of innocence which is reasonable in the absence of contary facts becomes quite unrealistic when we include in the picture the facts that the person has been officially charged with the crime and has been brought to trial. . . . The instruction on "presumption of innocence" should, it seems, be regarded merely as a traditional but unnecessary amplification of the instruction on the prosecution's burdens of evidence and of persuasion beyond a reasonable doubt.

Id. See also J. Thayer, A Preliminary Treatise on Evidence 551-76 (1898); 9 J. Wigmore, supra note $19, \S 2511$.

45. Concededly, the pre-trial process is less likely to screen out those whose guilt cannot be proved according to law if inadmissible evidence is utilized in making probable cause determinations. See United States v. Calandra, 414 U.S. 338 (1974).

46. See In re Winship, 397 U.S. 358 (1970). 
and practices whose roots are in the adversary system itself rather than in the objectives of our adjudicatory process.

Thus, in Hickman v. Taylor, ${ }^{47}$ counsel in a civil case was permitted to deny opposing counsel access to nonprivileged information of a kind that was relevant to a dispute requiring resolution. The decision was justified in large part upon the ground that to place the obligation upon each counsel to interview his own witnesses would encourage each to perform the role expected of him, while permitting one counsel to do nothing and then gain access to the statement procured by his adversary would, according to the Supreme Court, have a "demoralizing" impact upon the legal profession. ${ }^{48}$ Concededly, the decision was based partly upon the assumption that if each lawyer is required to perform his functions diligently, each will be in a better position to present evidence to the jury and thus better serve the ends of the adjudicatory process.

Belief in the wisdom of the adversary system is engrained in the legal profession. Much of modern procedural reform, such as simplified pleadings and discovery, has triumphed only after long arguments that the adversary system, and hence our entire system for the resolution of disputes, will be weakened if the combatant model of the adversary system is modified, much less abandoned.

But conduct that is justified in terms of its importance to the adversary system obviously stands on different, and far less firm, footing than conduct that finds its justification in the purposes of our system of adjudication itself. When a practice is defended solely on the ground that it is necessary to support the adversary system, it is fair to ask not only whether it will further the adversary system, but what its impact on the objectives of our adjudication process will be. If it is concluded that it directly and significantly tends to frustrate one or more purposes underlying our process of adjudication, the fact that it will advance the adversary system should normally be no excuse. Indeed, it is arguable that no practice should be defensible solely on the ground that it supports the adversary system. ${ }^{49}$

47. 329 U.S. 495 (1947).

48. Id. at 511. But of. Goldberg v. United States, 425 U.S. 94 (1976) (allowing defense counsel access to statement of key witness to prosecutor as provided for in the Jencks Act, 18 U.S.C. $\S 3500$ (1976)).

49. There are those who reject the notion that significant ethical questions, such as the mode of representation of a client who intends to commit perjury, can or should be resolved by deductive reference to a theory of the juducial process. See Essay, supra note 17, at 460 . Instead, it is suggested that the propriety of conduct can ultimately be judged by the lawyer alone, although the lawyer who acts in defiance of a clear consensus that his conduct is wrong may be subject to discipline. Id. 464-65. 


\section{B. Motion to Suppress for Want of Probable Cause.}

Presumably, most will agree that Jones proceeded properly when he moved to suppress admission of the sack and its contents, Smith's admissions to the deputy sheriff, and Ms. Young's eyewitness testimony identifying Smith. Indeed, a failure to do so would raise doubts about his competence, his ethics, or both. Each motion was aimed at the suppression of truth, but here it was unnecessary for Jones to balance the value of the ascertainment of truth against the value of deterring law enforcement agents from violating constitutional rights. The Supreme Court has already performed this function by determining that the conduct of the deputy sheriff violated the Bill of Rights and that suppression of highly reliable evidence of guilt is the necessary prophylactic. ${ }^{50}$ Jones' motions to suppress were directly related to one of the purposes of our adjudicatory process as it now exists-deterrence of wrongdoing by public officials. Jones, and some of us, may doubt whether materially enhancing the likelihood of acquittal of a bank robber will in fact deter future deputy sheriffs of Kenan County from unlawful actions, particularly if they are unaware that their actions are illegal. But that decision is for the courts, not counsel.

It appears that at least some members of the Supreme Court are now also questioning whether the losses to the truth-seeking process are really justified by the supposed deterrence. Recent decisions admitting illegally obtained evidence to impeach credibility ${ }^{51}$ and in hearings before grand juries, ${ }^{52}$ and particularly Mr. Justice Rehnquist's recent proposals that evidence should be suppressed only if it can be said that the law enforcement officer knew or should have known that his action was unlawful, ${ }^{53}$ certainly suggest concern over the degree to which we have permitted other values to limit the truth-seeking potential of a criminal trial. But that problem is for the courts, not Jones.

\section{Nondisclosure of Adverse Authority.}

Jones' conduct in arguing the motion to suppress is less defensible. You will recall that he did not reveal to the court a case decided in another jurisdiction directly in point on the issue of abandonment, although he had reason to know that the court would have liked to have known about the case before determining whether the fourth amend-

50. See, e.g., United States v. Wade, 388 U.S. 218 (1967); Miranda v. Arizona, 384 U.S. 436 (1966); Mapp v. Ohio, 367 U.S. 643 (1961).

51. Oregon v. Hass, 420 U.S. 714 (1975); Harris v. New York, 401 U.S. 222 (1971).

52. United States v. Calandra, 414 U.S. 338 (1974).

53. United States v. Peltier, 422 U.S. 531, 542 (1975). See also Stone v. Powell, 428 U.S. 465, 496 (1976) (Burger, C.J., concurring); United States v. Janis, 428 U.S. 433 (1976). 
ment had been violated. Jones' decision not to reveal the case from a sister state seems justified, at least by negative implication, by the language of the CPR, which in Disciplinary Rule 7-106(B) provides:

In presenting a matter to a tribunal, a lawyer shall disclose:

(1) Legal authority in the controlling jurisdiction known to him to be directly adverse to the position of his client and which is not disclosed by opposing counsel. ${ }^{54}$

This test is too narrow. Counsel should have the obligation of bringing to the attention of the court any authority about which he reasonably believes the court would like to know before deciding the matter before it. This was the professional obligation of counsel before the Code ${ }^{55}$ and far better reflects the appropriate obligations of an officer of the court. If Jones had informed the court of the unfavorable decision, he would, of course, have remained free to argue that it was not binding, that it was incorrectly decided or that factual differences between the decided case and the one before the court made the precedent distinguishable. Counsel should not be free to withhold precedent from the court in the hope of a favorable judgment when he appreciates that the case might influence the judge to rule against him.

The ineptitude or lack of diligence of opposing counsel or of the court is no justification for increasing the likelihood that a judge will incorrectly ascertain or apply the law. Neither is the understandable attitude of the client that his counsel should take no action that "will help the other side." There should be occasions, and there are, as in response to a demand for discovery, when counsel is obligated to act in a way that reduces his client's chances for acquittal. ${ }^{56}$ The appropriate role of a lawyer should not be and is not determined solely by what is in the interests of his client. Certainly he should explain to his client why he is revealing a case prejudicial to his argument. But his obligation to assist the court in ascertaining and applying the correct principle of law should be paramount. It is paramount, under the Code, when there is a case in point in his jurisdiction; it should also be paramount when there are cases in point in other jurisdictions significant enough to put counsel on notice that the judge would like to share counsel's knowledge before ruling.

54. CPR D.R. 7-106(B)(1).

55. See ABA Comm. on Professional Ethics, Opinions, No. 280 (1949).

56. See, e.g., United States v. Nobles, 422 U.S. 225 (1975); Williams v. Florida, 399 U.S. 78 (1970). 


\section{Differing Testimony Under Oath.}

Jones' successful objections to several of the evidentiary offers of the district attorney raise interesting issues. Jones was able to block the district attorney's attempt to introduce evidence of Smith's testimony at the suppression hearing that he lived at the mobile home and intended to return before the lease expired in two weeks, a statement directly in conflict with Smith's testimony at the trial that he had left town before the robbery and never planned to return. As a result, the jury was not aware that Smith had told a different story under oath in the same case.

The tactic seems permissible. Defense counsel did nothing more than the law of evidence permits. The prosecutor probably would have been able to obtain admission of the evidence if he had proceeded differently. ${ }^{57}$ Again, the wisdom of permitting a defendant in a criminal case to tell one story in a suppression hearing and another at a trial on the merits, and then to prevent the inconsistency from being revealed to the jury, seems questionable, but a defendant may do so under existing law, at least when the district attorney proceeds as he did in this case.

\section{E. Suppression.}

Judge Frankel would impose an ethical obligation on counsel to question witnesses with a purpose and design to elicit the whole truth. ${ }^{58}$ This approach seems unwise. If we want to learn all a witness knows, that is, "supplementary and qualifying matters that render evidence already given more accurate, intelligible or fair than it otherwise would be,"59 the remedy should be to broaden discovery and to expand the scope of cross-examination instead of placing the affirmative burden on defense counsel. Presumably, it is immaterial who brings forth the evidence; what is important is that the full story be developed. The problem, again, is not professional ethics that permit counsel to develop less than the whole truth; rather, the problem stems from the provisions of our procedural law that prevent an opponent from learning what has not been brought forth and that prohibit questioning of witnesses beyond the scope of direct examination. ${ }^{60}$

57. See United States v. Kahan, 415 U.S. 239 (1974); authorities cited at note 51 supra.

58. Frankel, supra note 13, at 1057.

59. Id. 1058

60. Id. 1057. Judge Frankel also urges that the CPR be amended to require that a lawyer report to the court and to opposing counsel when the lawyer does not intend to offer such evidence or witnesses, "unless prevented from doing so by a privilege reasonably believed to apply." Id. 
The cardinal principle that should govern counsel's conduct is that he may assert any right his client possesses under the law. The trial is not a process of determining moral culpability according to abstract principles of justice. It is a procedure to determine legal guilt in accordance with existing provisions of law. Counsel takes the law as he finds it. The law requires the state to prove guilt beyond a reasonable doubt by competent evidence. Counsel has a right, and indeed a duty, to insist that guilt be determined according to that law.

The same principle should govern the other more controversial actions by Jones: his failure to reveal the intimidated eyewitness and the gun used in the robbery; his cross-examination of Roberts while believing that Roberts was telling the truth; and his cross-examination of Edwards while knowing that Edwards was telling the truth.

The failure to reveal incriminating evidence is sometimes referred to as the "suppression issue." The issue in the hypothetical case has been phrased with some care. The attorney did not participate in the intimidation of the witness; he did not even know of the incident until near the end of the trial. He did not hide the guns, nor did he suggest directly or indirectly that they be hidden. He learned of both matters in confidence. Active involvement by a lawyer in the concealment of evidence, no matter how cautiously accomplished, is undoubtedly unethical and, depending upon state law, may constitute an obstruction of justice even when the suppression arises out of a confidential communication. $^{61}$ The more difficult question is posed when the attorney does nothing either to encourage concealment or to reveal it.

A strong argument can be made for the proposition that Jones might be required to reveal such matters if discovery permitted the state to demand production of any gun in the possession of the defend-

It is unclear whether the distinguished judge is talking about the privilege of confidential communications, the privilege against self-incrimination, or both.

61. See In re Ryder, 263 F. Supp. 360 (E.D. Va.), affd, 381 F.2d 713 (4th Cir. 1967); cf. Clark v. State, 159 Tex. Crim. 187, 195, 261 S.W.2d 339, 347, cert. denied, 346 U.S. 855 (1953) (conversation between attorney and client, in which attorney advised client to dispose of murder weapon, admissible upon testimony of eavesdropper because "not in the legitimate course of professional employment in making or preparing a defense"); State v. Olwell, 64 Wash. 2d 828, 833, 394 P.2d 681, 684 (1964) (though attorney may not be required to testify without client's consent, court stated "[w]e do not ... imply that evidence can be permanently withheld . . . under . . . the attorney-client privilege. [W]e must consider the balancing process between the attorney-client privilege and the public interest in criminal investigation"). But cf. N.Y. State Bar Ass'n Comm. on Professional Ethics, Opinions, No. 479 (1974), reprinted in 22 CRIM. L. REP. (BNA) 2537 (1978) (lawyer not required to reveal client's admissions of other crimes). See also Callan \& David, supra note 17, at 382; Comment, Legal Ethics: Confdentiality and the Case of Robert Garrow's Lawyers, 25 BufFalo L. REv. 211 (1975); Comment, The Right of a Criminal Defense Attorney to Withhold Physical Evidence Received from His Client, 38 CHI. L. REv. 211 (1970). 
ant or to demand names and addresses of any witnesses having knowledge of the crime as part of the process conferring equal or broader discovery rights upon the defendant. The argument against an obligation to comply under these circumstances would probably be grounded on the fifth amendment, but whether it would prevail after recent cases narrowing the coverage of this amendment ${ }^{62}$ is at least open to conjecture. The point is that if there should be any obligation of counsel to volunteer evidence prejudicial to his client's interest learned in confidence, such an obligation should depend upon a procedure in which the state requests such evidence in compliance with constitutional standards.

The failure to reveal does, of course, reduce the likelihood of the truth emerging from the trial (or, at least, the likelihood of its being reflected in the jury's verdict). However, a distinction should be made between counsel's obligation not to take action that will suppress the truth or mislead the jury, in the absence of special justification, and an obligation to take affirmative action to produce additional evidence for the jury's consideration. ${ }^{63}$ Certainly, no such obligation should exist until the dimensions of the fifth amendment are more clearly defined. To require revelation of evidence by a defendant through his counsel in the absence of a reciprocal right of discovery might well constitute a violation of the fifth amendment. Defense counsel should not have the obligation of determining the coverage of the fifth amendment as he would under Judge Frankel's proposal. As Disciplinary Rule 7-109(A) suggests, a lawyer unethically suppresses only when he or his client has a legal obligation to reveal or produce. ${ }^{64}$ The source of any legal obligation should be the procedural law of the state, not the ethics of the profession.

\section{F. Cross-Examination.}

Effective cross-examination of a witness known or believed to be telling the truth raises one of Dean Freedman's Three Hardest Questions. ${ }^{65}$ In the hypothetical, you will recall that Roberts was crossexamined on the basis of a fifteen-year-old conviction for a crime unre-

62. See United States v. Nobles, 422 U.S. 225 (1975); Williams v. Florida, 399 U.S. 78 (1970); $c f$. Wardius v. Oregon, 412 U.S. 470 (1973) (reciprocal discovery of alibi evidence is required by fundamental fairness); Brooks v. Tennessee, 406 U.S. 605 (1972) (statute requiring defendant to testify before any other defense testimony is heard if he is ever to do so violates the privilege against self-incrimination). See also Fisher v. United States, 425 U.S. 391 (1976); Couch v. United States, 409 U.S. 322 (1973).

63. See Uviller, supra note 13.

64. CPR D.R. 7-109(A).

65. See note 6 supra. 
lated to veracity under circumstances where the revelation of the crime might seriously injure his reputation and security, and where the judgment of several jurors concerning his credibility might well be affected by proof of the conviction. He was also cross-examined on the basis of his capacity to observe the incident related on direct examination, although his testimony on direct was not at all inconsistent with the story that had been related to Jones by the defendant. Edwards' credibility, too, was impeached when Jones showed the possibility of bias growing out of his deal with the district attorney and on the basis of prior convictions.

The Code speaks to this issue only in a most general and ambiguous passage that prohibits advancing a "defense that is unwarranted under existing law." The ABA Standards Relating to the Defense Function would seem to condemn Jones' behavior. Section 7.6(b) provides:

A lawyer's belief that the witness is telling the truth does not necessarily preclude appropriate cross-examination in all circumstances, but may affect the method and scope of cross-examination. He should not misuse the power of cross-examination or impeachment by employing it to discredit or undermine a witness if he knows the witness is testifying truthfully. ${ }^{67}$

Clearly, the Standard is specifically directed at Dean Freedman's conclusion that such conduct is justified, although there is no reference to Dean Freedman's article in the commentary or bibliography of the Standards.

In my judgment, Dean Freedman's conclusion is correct as a matter of principle. ${ }^{68}$ A defendant should be convicted only if the state proves his guilt beyond a reasonable doubt. Cross-examination is one of the most important techniques available for creating a reasonable doubt. Indeed, prior to the nineteenth century reforms that made a defendant competent to testify, cross-examination was sometimes the only weapon available.

66. CPR D.R. 7-102(A)(2). Even then, counsel may advance a claim if it can be supported by a good faith argument for an extension, modification or reversal of existing law. See Thode, Canons 6 and 7: The Lawyer-Client Relationship, 48 TEx. L. REv. 367 (1970).

67. ABA Standards 7.6(b); $c f$. State v. Fleury, 111 N.H. 294, 282 A.2d 873 (1971) (defendant not denied effective trial counsel based on attorney's failure on cross-examination to ask questions that would have elicited only repetitive testimony damaging to defendant; no need to press objections to pre-trial identification process where other procedures clearly establish validity of the identification).

68. Compare Burger, supra note 9, with Bowman, Standards of Conduct for Prosecution and Defense Personnel: An Attorney's Viewpoint, 5 AM. CRM. L.Q. 28 (1966); compare N.Y. County Opin. 43 (1914), quoted in V. CountryMan, T. FinMaN \& T. SCHNEYER, THE LAWYER IN MODERN SOCIETY 291 (2d ed. 1976) with CPR D.R. 7-106(c)(2). 
Counsel should be allowed to ask any questions permitted by the law of evidence in his efforts to test the observation, recollection and credibility of the witness. He fulfills his obligation to the court when he takes care not to ask questions forbidden under the law of evidence. He fulfills his obligation to his client when he asks any legally permissible question, the answer to which may raise a reasonable doubt in the mind of a juror. He owes no obligation to the witness except to examine him according to law. Indeed, the CPR specifically provides that a lawyer shall not intentionally fail to seek the lawful objectives of his client (that is, to create a reasonable doubt) through reasonably available means permitted by law and the Disciplinary Rules. ${ }^{69}$

Indeed, counsel's right to proceed in this manner may be viewed as the converse of the prohibition against asking a question, the answer to which is inadmissible, or intentionally violating an established rule of evidence, ${ }^{70}$ tactics sometimes employed for the purpose of suggesting the improper material to the jury with full knowledge that an instruction to disregard the question will be ineffective. Moral certainty of guilt by counsel is not the equivalent of a jury verdict. Matters that will mitigate moral culpability are frequently inadmissible under the law of evidence, and it is unprofessional for a lawyer to allude to any such matters. ${ }^{71}$ The underlying reason is that the trial must be conducted under a set of rules. If those rules permit a certain form of cross-examination, there is no convincing reason why it should not be used.

Part of the problem is again one of evidence, not ethics. Few students of the criminal process believe that a fifteen-year-old conviction of an offense unrelated to veracity has any significant impact on the credibility of a witness. Most recognize that proof of such stale prior convictions should not affect credibility, may needlessly injure the reputation of the witness and frequently will be misused by the jury. ${ }^{72}$ One alternative is to exclude proof of such convictions. A second is to entrust their admissibility to the discretion of the judge and concomitantly to charge him with the responsibility of balancing the value to be

69. CPR D.R. 7-101(A)(1). The only exceptions provided for in the Disciplinary Rules are (1) where permissible, a lawyer may exercise his professional judgment to waive or fail to assert a right or position of a client and (2) a lawyer may refuse to aid or participate in conduct that he believes to be unlawful.

70. CPR D.R. 7-106(C)(1), D.R. 7-106(C)(7); cf. CPR D.R. 7-106(C)(2) (question that is intended to degrade a witness or other person).

71. CPR D.R. 7-106(C)(1).

72. See Fed. R. Evid. 609(b); Ladd, Credibility Tests-Current Trends, 89 U. PA. L. Rev. 166, 176-77 (1940). 
gained against the losses suffered by their use. ${ }^{73}$ The first approach might have prohibited the use of convictions to impeach Roberts (the janitor) or Edwards (the robber); the latter probably would have protected only Roberts. The supposed issue of ethics would be much less significant if different rules of evidence prevailed.

There is understandably a desire to avoid the conclusion that a lawyer can do anything not prohibited by rules of evidence or procedure or law. Thus, the argument is advanced that a cross-examination may be proper when a lawyer believes the witness is untruthful, inaccurate in recollection or narration, or has told less than the whole story, but not when the lawyer believes (or knows) that the witness has honestly narrated an accurate version of the events he perceived. ${ }^{74}$ The argument is persuasive in that it presumes a model of professional deportment in which the attorney adheres to a quest for abstract justice. The fallacy lies in the relationship between the standard of proof required for conviction and the function of defense counsel in challenging all evidence adduced by the state in the effort to meet that standard. A defendant should be convicted only when the prosecution's case, after subjection to the kind of cross-examination permitted by law, establishes guilt beyond a reasonable doubt. There is no way to ascertain whether such a level of proof has been reached if counsel declines to cross-examine because of his personal belief in the credibility of the state's witness.

There are pragmatic reasons for permitting cross-examination of Roberts' capacity to observe and of Edwards' honesty. Jones' belief that Smith was in the car may be wrong because both Smith and Roberts may be lying. Edwards may be telling a story that is basically true, but he may have embellished it to ensure the favorable treatment he has bargained for in exchange for his testimony. The appearance created by Jones' attack on the witnesses is troubling, but on balance his conduct was justified.

73. See Luck v. United States, 348 F.2d 763 (D.C. Cir. 1965); Fed. R. Evid. 609.

74. Perhaps the most eloquent expression of this view is found in H. MACMILLAN, LAw \& Other THings (1937):

Again, suppose that your opponent's leading witness has to your knowledge many years ago been guilty of some offence, but has long outlived it and by honourable conduct completely wiped out all public recollection of it. Your client perhaps urges you to ask him in cross-examination a question reviving this long-erased blot upon his escutcheon in order to discredit his present evidence. What are you to do? If the witness to the best of your judgment is giving his evidence truthfully and fairly, you will decline to deal a cowardly blow at him through his past.

Id. 192. 


\section{G. Social Sciences and Voir Dire.}

The use of the psychological profile and similar techniques drawn from the social sciences poses yet another problem. ${ }^{75}$ Lawyers have always attempted to select jurors believed either to be favorably disposed to their clients' causes or individuals to whom they can "sell a case." Only recently, however, have social science techniques been utilized to determine the identity of jurors whose attitudes about and approaches to a wide range of issues will predispose them to vote in a certain manner on a particular case. The practice has been defended as a return to the early concept of a jury in which the defendant's friends presumably sat with others from the neighborhood, as a necessity to combat prejudice and as a desirable reinforcement of the presumption of innocence. Whatever its rationale, the profile, when considered with the substantial number of peremptory challenges made available to a defendant in a felony case, makes it possible for defense counsel to minimize the dangers of conviction to a much greater degree than if jurors were chosen without knowledge of their attitudes and prejudices. The result is a defendant's jury rather than the cross-section of the community that is more likely to occur when such techniques are not used. It is one thing to prove guilt beyond a reasonable doubt to a jury which is "impartial" or which reflects a cross-section of the community. It is quite another to convince a jury beyond a reasonable doubt when the jurors selected are biased in favor of a defendant, the cause he represents or the defense he will assert.

Psychological profiles have been used in such celebrated "political" trials as the Angela Davis, the Joan Little and the Mitchell-Stans cases; ${ }^{76}$ similarly, defense counsel conducted thorough investigations of prospective jurors' backgrounds in the Daniel Ellsberg case. As a practical matter, such techniques increase the government's burden regardless of the formal standard of proof. Thus far, the costs have been so great that use of the technique has been infrequent and has been confined to "political" cases. If the practice becomes more routine, it may constitute another threat to the likelihood that the jury's verdict will accurately reflect the defendant's guilt or innocence.

There are some who argue that the jury is a political institution and that the verdict properly reflects the prejudices of the community (at least if the jury acquits). ${ }^{77}$ The problem is of much greater signifi-

75. For a brief and provocative discussion, see McConahay, Mullin \& Frederick, supra note 31, at 221-24.

76. See id. 205.

77. See Van Dyke, The Jury as a Political Institution, 16 CATH. Law. 224 (1970). See also M. Kadish \& S. Kadish, Discretion to Disobey: A Study of LaWful Departures from 
cance for those who believe that the jury should reflect a cross-section of the community and that it should, insofar as possible, find the facts with scrupulous adherence to the instructions of the court. ${ }^{78}$ The ABA Standards come no closer to the problem than asserting that a lawyer should restrict himself to investigatory methods that will not harass or unnecessarily embarrass potential jurors nor invade their privacy and, whenever possible, should restrict his investigation to records and sources of information already in existence. ${ }^{79}$

This is another area where permissible constraints are more properly within the domain of procedural law than of professional ethics. Prohibitions against the use of a psychological profile or investigation of the backgrounds of jurors may well be unconstitutional. But there are other ways to deal with the problems if the frequency of use endangers the vitality of the jury system. Peremptory challenges may be reduced; legislation to protect the privacy of jurors and records may be expanded; ${ }^{80}$ concepts of venue may be modified. We should not deal with the problem by attempting to preclude counsel from taking action that is lawful under existing procedures.

\section{H. Perjury and Confidentiality.}

There are other areas in which Jones' conduct is much less defensible. It is one thing to fail to reveal the identity of a witness, to crossexamine a witness believed to be truthful and to suppress evidence unlawfully seized; it is completely another to suborn perjury in any form. Jones' conduct in lecturing Smith concerning the legal consequences of different versions of what might have taken place was no more or less than a suggestion of the story that Smith should then relate. ${ }^{81}$ It was intended to produce the version of the facts related by Smith and was obviously so perceived by him.

The reason for Jones' approach is likewise obvious. He might feel uncomfortable if he were required to call Smith to the stand to testify to a story that Smith had earlier denied. Jones is in a much better position from the point of view of his conscience and of his ultimate success if he can start with a story that, if believed, will justify an acquittal. Smith also is happier if he can provide such testimony.

Legal Rule (1973); Kaufman, The Right of Self-Representation and the Power of Jury Nullification, 28 CASE W. RES. L. REv. 269 (1978).

78. See Christie, Lawful Departures from Legal Rules: "Jury Nullification" and Legitimated Disobedience, 62 CAL. L. REv. 1289 (1974).

79. ABA STANDARDS 7.2(b).

80. See Babcock, Voir Dire: Preserving "Its Wonderful Power," 27 STAN. L. Rev. 545 (1975) (arguing for expansion of voir dire and limiting private investigation of jurors).

81. See G. HAZARD, supra note 21, at 128. 
It clearly would make a better battle in many cases if the defendant had help in fabricating his story. The problem is that we are seeking not a good fight but an honest statement of the events as perceived by the witness. The ABA Standard is clearly correct when it states:

It is unprofessional conduct for the lawyer to instruct the client or to intimate to him in any way that he should not be candid in revealing facts so as to afford the lawyer free rein to take action which would be precluded by the lawyer's knowing of such facts. ${ }^{82}$

The proper conduct of counsel when the defendant tells his lawyer he committed the crime, but indicates his intention to deny complicity when he testifies, poses a different problem. Dean Freedman concludes that in such a situation counsel should advise the client to tell the truth, but may then call the client to the stand, elicit the perjury and urge the jury to believe the perjury because to do otherwise "would be a betrayal of the assurances of confidentiality given by the attorney in order to induce the client to reveal everything, however damaging it might appear." 83 The problem is that to permit such conduct would clearly undermine the adjudicatory process.

There is no vital difference between a lawyer suborning perjury from his client and a lawyer suborning perjury from another witness. Nor is the source of his knowledge of the perjury fundamental. Obviously, a prohibition against a lawyer suborning perjury from witnesses who are not his clients when he knows the truth from nonconfidential sources poses a less difficult problem. Dean Freedman apparently agrees that it would be unprofessional to call a witness, other than a member of the defendant's family, to testify to what is known to be a lie, although he would justify the attorney's facilitation of lying by close family members. ${ }^{84}$

What is it that excludes the defendant and close members of the family from the normal operation of the rule? We are told in substance that it is simply too much to expect people faced with criminal prosecution not to lie and that such persons need the absolute protection of confidential communications to bolster them in their contest with a hostile system. Defendants, it is said, will be less likely to tell the truth if they realize that the truth may limit their defense, and, unless they tell the truth, defense counsel may be unaware of salient points that may be available to assist them. In short, it is asserted that the level of protection that the state should afford the individual is one that permits the defendant to have his cake and eat it too: he may tell

82. ABA STANDARDS 3.2(b).

83. M. FREEDMAN, supra note 17, at 31.

84. Id. 32 . 
the truth in order that the lawyer can use those portions of it that may be helpful, but he may also lie if the truth alone is inadequate to assure his acquittal. The lawyer may help him to make the lie more plausible by adroitly examining him and by arguing that he is a credible witness.

Clearly, the confidential relationship is of immense significance to the operation of our system. But there is nothing in the history of the evidentiary privilege or of the professional obligation to suggest that it was designed to cloak active participation in the facilitation of perjury. A conclusion that a lawyer may immunize himself from professional responsibility for subornation by telling his client that his conduct is unlawful lacks a basis in authority or reason. Whether or not he has previously cautioned a client to tell the truth, when an attorney calls the client to the stand knowing that he will lie, the attorney willfully procures perjury.

A broader justification for counsel calling any witness (including but not limited to the defendant) when he knows he will tell a falsehood is predicated upon the proposition that counsel is not required to be the judge of the credibility of any witness, including his client. It is argued that the trial is not a search for "truth" in the abstract, but is rather an effort to persuade the trier of fact that it should resolve the dispute by adoption of some version of the facts as testified to by witnesses. Such an approach is asserted to be consistent with the position taken earlier in this Article, which justified the cross-examination of a witness known to be telling the truth. ${ }^{85}$

Advocates of this approach would argue that counsel should advise witnesses and clients to testify only to what they believe in their own minds to be the truth and warn them of the pains of perjury and of the danger of effective cross-examination of a witness who is not truthful. After such warnings, the lawyer has arguably fulfilled his duty. He should not attempt to judge credibility but should permit the witness to relate any story the witness desires and then attempt to persuade the jury to believe the testimony elicited. ${ }^{86}$

There is obvious appeal in such an analysis. Counsel is relieved of any ethical responsibility if a witness chooses to lie. Undoubtedly, defense counsel will sometimes be more successful than would have been the case if he could not have produced witnesses to testify about a defense that counsel knows did not exist.

85. See text accompanying notes 65-74 supra.

86. This argument was eloquently advanced as a hypothesis deserving careful attention in a letter from Justice James G. Exum, Jr. of the Supreme Court of North Carolina to the author (Dec. 1, 1977) (on file at Duke Law Journal). 
The problem is that in some situations lawyers do "know" what in fact took place. When they do, the moral responsibility for producing testimony to the contrary is quite different from when counsel is ignorant of the true state of facts, or even when he believes (but does not know) that the facts are different from the version of the facts that the witness is prepared to relate. Knowledge simply brings with it moral consequences that are not present in its absence.

Furthermore, it is frankly impossible to explain to the public why a lawyer should be permitted to present with impunity evidence he knows to be false. It makes little difference whether the evidence is live testimony or a document. The public expects that the conduct of lawyers in a courtroom will be at least equal to the behavior expected of laymen in the ordinary affairs of life. To examine a witness who is telling a story under oath that the witness and the lawyer know to be false does not meet the minimum standard of conduct.

It is submitted that the lawyer should lay out the ground rules that will govern his representation at his first conference with the defendant: he will ask his client to relate his version of the facts. Counsel will not permit him to take the stand and testify to facts that the defendant has told counsel did not take place. After hearing the defendant's version, the lawyer will conduct his own investigation. If the lawyer's investigation of the case reveals evidence that tends to refute the defendant's story, and he concludes that the defendant's story will not be believed, he will so inform the defendant. If the defendant recants, the lawyer will then either attempt to negotiate a favorable plea agreement with the prosecutor or go to trial with the hope of preventing the government from meeting its burden of proof. If the defendant adheres to his story, counsel will proceed to trial, permit the defendant to testify if he so desires, and argue his version of the facts to the jury. Counsel will not, however, permit the defendant to change his version of the facts to meet the discovered unfavorable evidence. If the defendant either before or during trial changes his story and attempts to testify to a version of the facts earlier denied (unless this version of the facts is substantiated by counsel's independent investigation), counsel will seek to withdraw from the case. The client should be told that the lawyer's action in seeking to withdraw may or may not be permitted by the court and may have substantial impact upon the sentence imposed in the event of conviction.

Such caution at the beginning of representation might reduce the level of trust that the client has in counsel. It should. The client at the 
beginning should know that his lawyer is a "hired gun"; 87 he is a professional who will zealously represent him, though only within certain limits. The client should be informed of the scope of these limits.

This approach might also encourage some clients to lie initially. I doubt that this would occur frequently in cases involving a first offense, but more experienced defendants might well prefer to take a chance at acquittal by lying rather than accept the more limited defense that would be permitted if they were truthful. The price they will pay is that their counsel may be unprepared for some facets of the case because the defendants have failed to reveal the information counsel needs for adequate preparation.

No fundamental harm to the attorney-client relationship would result from such a practice. A client would simply be informed that the relationship, and the privilege designed to further it, do not go so far as to authorize the assistance of the attorney in the commission of future offenses-a traditional limitation that has never excluded perjury from its coverage. ${ }^{88}$

Concededly, some see a problem when a lawyer presents the testimony of a defendant whom he believes (but does not know) to be lying. Judge Frankel apparently equates cases in which an advocate has been informed directly by a competent client of his guilt with those in which counsel has, from other evidence too clear to admit of genuine doubt, learned that his client's position rests upon a falsehood. ${ }^{89}$ The cases are distinguishable. There is a great deal of difference between a lawyer calling to the stand a defendant who has asserted his innocence, although the other evidence in the case persuades the lawyer of his probable guilt, and the same lawyer calling a defendant to the stand when the defendant has told the lawyer that he will lie. The principle that a lawyer should not call a client to the stand when he knows he will lie applies only to the situation where the client has told the lawyer that $X$ is true, but that he will testify to $Y$, and the lawyer's independent investigation establishes that $X$ is true. If his client tells him from

87. See Dash, The Emerging Role and Function of the Criminal Defense Lawyer, 47 N.C. L. REv. 598, 630 (1969).

88. See CPR D.R. 7-102(A)(7) (lawyer shall not "counsel or assist his client in conduct that the lawyer knows to be illegal or fraudulent"); E.C. 7-5 (lawyer may not "knowingly assist the client to engage in illegal conduct"); ABA STANDARDs 3.7(b) (unprofessional conduct for lawyer to "counsel his client in or knowingly assist his client to engage in conduct which the lawyer believes to be illegal").

89. Frankel, supra note 13, at 1039; $f$. CPR D.R. 1-102(A)(4) (lawyer shall not engage in conduct "involving dishonesty, fraud, deceit, or misrepresentation"); D.R. 1-102(A)(5) (lawyer shall not engage in conduct "that is prejudicial to the administration of justice"). 
the beginning that $Y$ is true, the lawyer should be able to call the witness to testify to $Y$, even if the attorney is convinced to a moral certainty that $Y$ is untrue. The impact on the jury may be the same, but the ethical posture of the lawyer is quite different. ${ }^{90}$

It is my understanding that this is what is meant by the CPR's prohibition that a lawyer shall not "knowingly use perjured testimony"91 and by the Code of Trial Conduct of the American College of Trial Lawyers' provision that "[a] confidential disclosure of guilt alone does not require a withdrawal from the case, but he [the lawyer] should never offer testimony which he knows to be false."92 As long as the defendant asserts his innocence, the lawyer should assist him in presenting his case to those with the responsibility of determining guilt or innocence. The attorney should not prejudge guilt in any case except where facts establishing guilt are admitted by the defendant and confirmed by his investigation.

In a retained case, if the client plans to give testimony the lawyer knows to be false, he frequently will be able to withdraw. In some cases the client may be candid with his second counsel to avoid the possibility of another withdrawal; in others he may lie at his initial conference with the second lawyer. In the latter case, the same story may be presented to the jury as if the first counsel had remained in the case and permitted the defendant to relate a story that he knew to be false. But professional responsibility should be determined not by what the jury hears but by the knowledge and behavior of counsel. The argument that the likelihood of perjury is greater because the new counsel is ignorant of the falsehood, and therefore not in a position to discourage the client from presenting it, is specious. If the first attorney could not prevail upon the defendant to tell the truth, there is no reason to believe the second would have been more successful.

If the defendant is an indigent and the motion for leave to withdraw is made substantially before trial, the motion will be granted in

90. See Thode, supra note 66, at 369-70. "D.R. 7-102(A)(1) makes clear that not only what a lawyer does, but why he does it is relevant to a determination of whether he is acting 'within the bounds of the law." Id. Another distinction would also be appropriate. A lawyer might believe his client is about to commit perjury, but have no firm factual basis for the belief. Discussion of his conjecture with the trial court in these circumstances would clearly be improper. See United States ex rel. Wilcox v. Johnson, 555 F.2d 115, 122 (3d Cir. 1977).

91. CPR D.R. 7-102(A)(4) (emphasis added).

92. American College of Trial lawyers, Code of Trial Conduct 4(a) (1972 rev.) (emphasis added); $c f$. Gold, Split Loyalty: An Ethical Problem for the Criminal Defense Lawyer, 14 Clev.-MAR. L. Rev. 65 (1965) (attorney must preserve duty to client by avoiding court's improper questions requiring candid answers and by not volunteering information detrimental to client). 
many cases. It is true that in a single-judge court the judge will probably be aware of the cause of the motion without any confidence being revealed. This is not an unfair price to be exacted from a defendant who insists upon pursuing his efforts at perjury. In a multi-judge court, even this disadvantage may not exist.

A motion for leave to withdraw on the eve of trial may well be denied. It is not disingenuous to urge that counsel should move for leave to withdraw, while recognizing the likelihood of denial of the motion. ${ }^{93}$ The point is that counsel should manifest to the court that he is unable both to represent this defendant effectively and to adhere to the Disciplinary Rule that admonishes him not to "knowingly use perjured testimony or false evidence." 94

It is not inappropriate that a motion for leave to withdraw in such a situation "passes on" the problem to the judge. ${ }^{95}$ He must balance the disadvantages of delay and the possibility of perjury at a later trial against the probability of perjury if the motion is denied. If we begin to place more emphasis upon the avoidance of perjury and less on docket delay, we might find more withdrawals permitted and more defendants who - having learned of the consequences of their insistence upon perjury-think twice before insisting upon it. If a judge denies the motion, he has in effect ruled that the danger of perjury is outweighed by the need to proceed expeditiously.

Much the same problem is involved when the client "spins"96 his counsel at trial, as Smith did to Jones. Here, the ABA Standard asserts that the lawyer should make a record of what has happened without revealing the matter to the court. ${ }^{97}$ A far better procedure would require counsel to move for leave to withdraw and permit the court to declare a mistrial. Again, the responsibility should be borne by the trial judge. If the court believes the danger of perjury is less important than continuing with the case, the court may so rule. A mistrial in such a situation should not bar retrial. ${ }^{98}$

The ABA Standard also adopts the position that if a pretrial motion to withdraw is denied, or if the problem arises at trial, it is unprofessional for the lawyer to examine the witness in the conventional

93. Contra, M. FREEDMAN, supra note 17, at 34.

94. CPR D.R. 7-102(A)(4).

95. But see People v. Brown, 54 Ill. 2d 2l, 294 N.E.2d 285 (1973), to the effect that "the lawyer is obligated not to present testimony that he is satified is not true, and he cannot call upon the trial judge to make the decision for him." Id. at 24,294 N.E. 2 d at 287.

96. "Spinning" describes the situation in which a witness relates a story to counsel on the stand quite different from the one he related to counsel before trial.

97. ABA STANDARDS 7.7(c).

98. See McKissick v. United States, 398 F.2d 342, 344 (5th Cir. 1968). 
manner and later argue that the defendant's known false version of the facts is worthy of belief. ${ }^{99}$ By this criterion, Jones' behavior was unethical. But it is submitted that Jones behaved properly and that the ABA Standard is unwise.

If the court determines that the case should proceed, counsel should be authorized to act as he normally would, examining his client and arguing the client's version of facts to the jury. He should not abandon his client, in substance leaving the client unrepresented, which would be the certain result of compliance with the ABA Standard. ${ }^{100}$

Perjured testimony will occur, but the lawyer will have met his responsibility by asking to be relieved from participating in it. The court will have, as it should have, the obligation of determining whether society is best served by ordering a mistrial or by permitting the perjury to take place. The defendant will not be left unrepresented but may be deterred by the knowledge that, if convicted, he will be sentenced by the judge who required his counsel to continue with knowledge that counsel preferred to be relieved for ethical reasons.

Neither the suggested approach nor that of the ABA goes as far as that apparently advocated by at least one court of appeals in McKissick

99. ABA STANDARDS 7.7(c).

100. Professor Addison Bowman has argued that the system should not countenance a process in which defense counsel is required to present his client's testimony in a fashion that may lead the jury to believe that counsel does not believe his client. See Bowman, supra note 68, at 30. Professor Bowman's position is supported by State v. Robinson, 290 N.C. 56, 224 S.E.2d 174 (1976). In Robinson, discord developed between the defendant and his court-appointed counsel because of counsel's refusal to be a party to the introduction of what he reasonably believed to be perjured testimony. The defendant indicated that he did not wish to be represented by counsel. The trial court declined to relieve counsel, but indicated that it would not require counsel to examine a witness who counsel thought would lie. The witness was called, and counsel conducted preliminary examination leading up to the events that gave rise to the prosecution. At that point, counsel told the witness, "Tell what you would like to tell." The witness told her story, at which point the defendant personally took over the examination of the witness with counsel seated at the counsel table. The Supreme Court of North Carolina held that the defendant had been denied due process of law, noting that "[t] his procedure could hardly have failed to convey to the jury the impression that the defendant's counsel attached little significance or credibility to the testimony of the witness, or that the defendant and his counsel were at odds. Prejudice to the defendant's case by this trial tactic was inevitable." Yd. at 67, 224 S.E.2d at 180. But see People v. Lowery, 52 Ill. App. 3d 44, 47, 366 N.E.2d 155, 157 (1977), approving the ABA Standard. The Robinson case has been criticized on the ground that it precludes a "compromise solution" between facilitating perjury by the client and revealing the client's confidence. See Note, Professional Responsibility - North Carolina's View of the Lawyer and the Perjurious Witness, 55 N.C. L. REv. 321 (1977). The problem of appropriate procedure in the situation with which Standard 7.7 deals has been the subject of other cases, none of which provides a definitive answer. See State v. Lowery, 111 Ariz. 26, 523 P.2d 54 (1974); Thornton v. United States, 357 A.2d 429 (D.C.), cert. denied, 429 U.S. 1024 (1976); People v. McCalvin, 55 Ill. 2d 161, 163-65, 302 N.E.2d 342, 344-45 (1973), cert. denied, 416 U.S. 909 (1974) (prior to Lowery). The cases are discussed in Polster, supra note 17, at 18-29, along with a criticism of Standard 7.7. 
v. United States. ${ }^{101}$ McKissick, a defendant who was tried on an information that charged him with selling drugs without prescription in violation of federal law, took the stand and testified. At the conclusion of his testimony, the trial judge commented: "This is the worst case of perjury in this case I have ever seen since I have been on the Bench; the drug agent or this witness, one, did it. I don't know who; I don't know which one of them did it."102 The next morning, before the jury retired, counsel requested a conference in chambers and in the presence of the prosecutor revealed to the judge that McKissick had told him, after testifying, that the testimony was false. Counsel stated that under these circumstances he did not feel that he could continue to represent McKissick and asked for a mistrial. The trial judge stated that he saw no alternative except to grant a mistrial because of the withdrawal of counsel. A mistrial was declared and McKissick, represented by a different counsel, was retried. On appeal from this conviction, he claimed double jeopardy. The court of appeals dismissed the claim of double jeopardy, holding there was "manifest justification or necessity" for the mistrial. It observed that the defendant "had no constitutional right, overriding the public interest, to have his case determined by a tribunal whose processes he had himself thus frustrated and abused." 103 On the question of the propriety of defense counsel's behavior, the court stated:

If the appellant told his attorney that he had committed perjury, that offense was in effect a continuing one so long as allowed to remain in the record to influence the jury's verdict. Whether appellant did or did not specifically authorize or direct his attorney to make it known to the court, or even directed it not be made known, he could not abrogate the attorney's discharge of his professional, ethical and public duty to report it. The statement was good cause to the attorney to withdraw from the case, and he would have been subject to discipline had he continued in the defense without making a report to the court. The attorney not only could, but was obliged to, make such disclosure to the court as necessary to withdraw the perjured testimony from the consideration of the jury. ${ }^{104}$

The court went on to decide that, while counsel acted properly in informing the court of his client's perjury, he should not have sought the mistrial, and that the revelation of the client's perjury by the lawyer should not have occurred in the absence of the client. It remanded the case to the district court to determine if there had been a waiver or if the constitutional error was nonprejudicial. On remand, the district

101. 379 F.2d 754 (5th Cir. 1967), discussed in Polster, supra note 17, at 16-18.

102. 379 F.2d at 758.

103. Id. at 761 .

104. Id. 
court found no waiver and no injury. A different panel of the Fifth Circuit affirmed the judgment. ${ }^{105}$ A petition for rehearing en banc was denied. ${ }^{106}$ Thus, six judges of the circuit approved the conduct of counsel and no active judge on the court of appeals sought a rehearing en banc.

In McKissick the perjury occurred before the lawyer had knowledge of the falsehood, but also before the jury had begun its deliberations. McKissick thus falls between the more classic cases where a perjury is learned of either after the proceedings are terminated or before the witness is called. It seems clear, however, that in the Fifth Circuit, counsel should not only seek leave to withdraw but should explicitly disclose the falsehood directly to the court. Such a requirement goes too far and is, arguably, inconsistent with the attorney-client privilege. ${ }^{107}$

In 1975 the ABA Committee on Ethics and Professional Responsibility grappled in Formal Opinion 341 with the apparent conflict between the lawyer's duty of candor to the court and his obligation to protect confidences. The Code now provides:

A lawyer who receives information clearly establishing that (1) His client has, in the course of the representation, perpetrated a fraud upon a person or tribunal shall promptly call upon his client to rectify the same, and if his client refuses or is unable to do so, he shall reveal the fraud to the affected person or tribunal, except when the information is protected as a privileged communication. ${ }^{108}$

The Committee concluded that the tradition of the bar that permits a lawyer to assure a client that information (whether a confidence or not) given to the firm will not be revealed to third parties is so important that it should take precedence in all but the most serious cases. The scope of confidences protected against mandatory disclosure is thus broader than the scope of those protected by the attorney-client privilege in the law of evidence. Exceptions are made for confidences or secrets the revelation of which is required by law or court order and for the intention of a client to commit a crime. The thrust of the opin-

105. McKissick v. United States, 398 F.2d 342 (5th Cir. 1968) (district court findings reported by appellate court, $i d$. at 343 ).

106. Id. at 344; accord, Polster, supra note 17, at 33-39, wherein it is argued that the lawyer should reveal the perjury to the court. Professor Wolfram is also in agreement. See Wolfram, supra note 17 , at $868-70$.

107. The reasons advanced for the privilege seem particularly pertinent to its operation in this context. See 8 J. Wigmore, ON Evidence \& 2291 (McNaughton ed. 1961); R. Lempert \& S. Saltzburg, A Modern Approach to Evidence 616-20 (1977).

108. CPR D.R. 7-102(B)(1). The background of Opin. 341 and the significance of the 1974 amendment to the Code are discussed in Note, Client Fraud and the Lawyer-An Ethical Analysis, 62 MinN. L. Rev. 89 (1977). 
ion is clear, however. The confidence will prevail in the event of a conflict. The commentary to the ABA Standards ${ }^{109}$ suggests that the duty to keep the confidence may be accorded even greater significance in criminal cases. ${ }^{110}$

\section{Conclusion}

In summary, Jones should have informed the court of the unfavorable precedent and should not have engaged in the Anatomy of $a$ Murder technique ${ }^{111}$ prior to eliciting Smith's statement, but his other conduct was justifiable. Nevertheless, his behavior will leave most dispassionate observers uneasy. Even when each individual action can be justified, there is a gestalt effect in which the total is more than the sum of the parts. The general picture is one of concerted activity aimed at achieving a result that is not in the public interest. The reasons are found partly in hard questions of ethics, but primarily in the law of evidence, including, but not limited to, the exclusionary rule. A distorted picture is achieved when each ethical question is isolated from the mosaic of which it is a part. Decisions concerning ethics cannot be disassociated from the other factors affecting the manner in which guilt will be determined. Presumably, there would be less concern if the evidence relevant to Smith's guilt, which was properly excluded under existing law, were available for jury consideration. The major source of concern is the combined effect of excluding the sack, the admissions of Smith, the eyewitness testimony and the prior inconsistent statement of Smith, while at the same time permitting cross-examination of witnesses known to be truthful and eliciting testimony known to be perjured.

It is time to re-examine how far we are prepared to go in seeking to accomplish in a criminal trial objectives other than the ascertainment of the truth of charges and defenses. As a part of this process, society must examine the dimensions of the exclusionary rule and other rules of evidence and procedure designed to assure that guilt or innocence is fairly determined. The profession must simultaneously examine our standards of professional responsibility in the light of the impact of different alternatives upon the objectives we have chosen.

109. See ABA Standards 7.7, Comment (Supp. 1971).

1i0. Whether courts will agree is at best conjectural. See State v. Henderson, $205 \mathrm{Kan} .231$, 468 P.2d 136 (1970). See also Note, supra note 108.

111. R. TRAVer, ANATOMY of A MURDER 32-35 (1958). Counsel explains "the law" to a client before ascertaining the client's version of the facts and does so in a manner that suggests that one version of the facts is consistent with innocence and that another is compatible only with guilt. 
There is, of course, an appealing symmetry in an approach that urges that a lawyer should never assess credibility and, hence, has the same range of tactics available to him in the defense of any client. The weakness of this position has been discussed previously. ${ }^{112}$

There is also symmetry and appeal in an approach that determines what tactics a lawyer may employ on the basis of counsel's belief in the justice of his cause, the integrity of his client or the honesty of a witness. Such a standard would clearly substitute the lawyer for the jury in resolving some issues involving credibility. In other circumstances, a standard of this nature would, as a practical matter, immunize a lawyer- himself protected by the attorney-client privilege-from effective scrutiny, much less the imposition of sanctions by the profession.

Nevertheless, there are clear problems involved in the thesis advanced in this Article. There is concededly a thin line between "belief" supported by overwhelming evidence and "knowledge" emanating from a client. There is also difficulty in distinguishing between cross-examining a witness known to be telling the truth and calling a client to the stand with knowledge that he will tell a falsehood. Each involves a foreseeable risk that the jury will be persuaded to accept a version of the facts that counsel knows is untrue. Each tactic is employed with that precise objective.

To the author, there is a material difference between testing whether the version of an event testified to by a witness who is honestly attempting to describe what he perceived meets the normal standards of perception, narration and factors affecting veracity, on the one hand, and eliciting a direct falsehood from a witness by an attorney who knows the witness is lying, on the other. The former is justified by the interaction between the nature of the adversary system and the obligations of the state to prove guilt beyond a reasonable doubt by testimony that has met the test of cross-examination permitted by law. No similar justification exists for the latter. Again, many dispassionate observers will disagree.

Unfortunately, there was little debate about these and other significant issues before the CPR was adopted by the ABA, and virtually none in most jurisdictions before it was incorporated into state law. With due respect to the distinguished committee that drafted the ABA Standards, too much effort was devoted to rebutting Dean Freedman's heresies and not enough to providing a conceptual foundation for the Standards adopted. Very few changes in the committee's recommen-

112. See text following note 86 supra. 
dations were made either in the Council of the Section of Criminal Justice or in the House of Delegates.

In 1979 the ABA will convene a national conference to examine the Code after its first decade. It is hoped that some of these issues will be addressed.

The challenge is here. The public can justifiably question the wisdom of permitting the legal profession to regulate itself if it is unable to meet the challenge forthrightly. If we do not want the role of a defense lawyer to be characterized as a "suppressor of truth," it will be necessary to modify either our current law of procedure and evidence or our code of ethics, or both. If the profession sees nothing wrong with the existing model, it must articulate its reasons to an unsympathetic public.

Our criminal process has achieved spectacular heights in the protection of the rights of our citizenry. Appreciation of these achievements must be coupled with a continued recognition that the ascertainment of truth remains an important fundamental value of our system of criminal justice. To lose sight of this value may place the legal profession in a posture similar to that of the English statesman whose "logical mind, starting from false premises, arrived unerringly at the wrong conclusion." 113

113. H. Macmillan, Winds of Change 451 (1966). 
